\title{
Contracts of Employment of Domestic Workers: Compliance with the South African Labour Law
}

\author{
Atang Azael Ntisa \\ Faculty of Management Sciences \\ Vaal University of Technology, Vanderbijlpark. South Africa \\ E-mail: atang@vut.ac.za \\ Jacob Selesho \\ Faculty of Management Sciences \\ Vaal University of Technology, Vanderbijlpark. South Africa \\ E-mail: jacobs@vut.ac.za
}

\section{Doi:10.5901/mjss.2014.v5n3p86}

\begin{abstract}
An employment relationship is the legal relationship created through the conclusion of a contract of employment between an employer and employee. Thus, it is assumed that determining the validity of employment contracts of domestic workers is an important matter for explaining the employment relationship in the current study. The target population in this study comprises domestic workers in the area of Vanderbijlark in southern Gauteng. The areas covered include: South-west 1; South-west 2; South-east 3; South-west 5; and South-west 5x1. Questionnaires were administered and interviews were conducted with the domestic workers who happened to be at the particular shopping centre or bus stop, at the particular time when the researcher was present for such purposes. Accidental sampling was chosen, because of its convenience. It can be concluded that a contract of employment should play an important role in clarifying what is to be expected from each party. The greater the clarity as to what is expected from each contractual party, the less the chance there is of misunderstandings in the relationship. Thus, no matter how widely domestic workers are covered by labour laws in the new South Africa, and no matter the efficiency of South African labour legislation, domestic workers will continue to be disadvantaged and exploited by their employers if they continue to form employment relationships in the absence of valid contracts of employment.
\end{abstract}

Keywords: Contract, Domestic Worker, Labour Relation

\section{Background of the Study}

Following the 1994 elections, the government of National Unity proposed a comprehensive reformation of South African labour policy. To this end, the four bastions of the framework, namely the Labour Relations Act (LRA) 66 of 1995; the Basic Conditions of Employment Act (BCEA) 75 of 1997; the Employment Equity Act (EEA) 55 of 1998; and the Skills Development Act (SDA) 97 of 1998 were promulgated to govern the employer-employee relationship (Venter \& Levy 2011:179). However, most contracts of employment of domestic workers are not in line with the requirements of these laws and when there is disagreement, domestic workers generally find themselves in a weaker position than their employers, who hold the purse strings (Tood 2001). In South Africa, some employers struggle with the relationship between contractual and legislation in employment relations (van Jaarsveld 2008:4). This unpleasant relationship manifests as a result of the contract of employment being the primary legal base of the employment relationship. The rules governing the labour relationship originate from mainly three sources: the common law; labour legislation; and collective bargaining (Grogan 2011:4). An employment relationship is the legal relationship created through the conclusion of a contract of employment between an employer and employee (van Jaarsveld \& Ingrid 2008). One of the requirements for a valid employment contract is that the parties must agree on the contractual terms that regulate their relationship (van Jaarsveld 2003). A contract of employment is defined as "an agreement between two or more legal persons, in terms of which one of the parties (the employee) undertakes to place his/her personal services at the disposal of the other party (the employer) for an agreed period in return for a fixed or ascertainable wage, and which entitles the employer to define the employee's duties and to supervise the manner in which the employee discharges them" (Venter \& Levy 2011: 182). One of the consequences of this contract is that one party, without the agreement of 
the other, cannot change it (Tood 2001).

Thus, it is assumed that determining the validity of employment contracts of domestic workers is an important matter for explaining the employment relationship in the current study. The focus will also be extended to the nature of the relationship between domestic workers and their employers and some unique characteristics which distinguish this relationship from relationships in other sectors of the labour market. Here, the question, in practice, is whether an employer's conduct is lawful and fair.

\section{Theoretical Rationale}

A legislative framework helps to shape labour relations' paradigms (Nel, Kirsten, Swanepoel, Erasmus \& Poisat 2008). The protection offered by the South African labour legislation and the International Labour Organisation (ILO) instruments, is applicable only to people who are defined as employees with an identifiable employer with whom they have an employment relationship; the corresponding legal instrument being a contract of employment (ILO 2002).

The discussion of the position of domestic workers in relation to a contract of employment in this study refers to domestic workers in private households. According to Grossett (1994) a domestic worker is any person who, inter alia, is involved in cleaning the contents of a private household; washing and ironing bed linen, towels and clothing in a private household; preparing and cooking meals for the household and guests, as well as washing up after meals; maintaining the garden of a private household, including watering, mowing, ranking, digging flower beds and keeping the swimming pool clean; and driving members of a private household to and from specific places; delivering and collecting groceries or other goods; and performs duties, such as collecting and delivering post. According to Ontario (2013) the following two issues should be considered in order to determine whether a worker is a domestic worker in a private household (household for dwelling purposes).

$>$ It is necessary to consider the nature of the work which he/she performs (domestic service).

$>$ The location of employer's business must be stipulated.

The terms of the contract of employment determine the consequences of the parties' contract. Certain terms are not stipulated in the contract, but are implied by the operations of the law. Owing to the over-all efficiency of the law, the vast majority of legal transactions and relationships never give rise to disputes or complications (Hahlo \& Kahn 1968). Historically, the contract of employment has served, and continues to serve, as the main "port of entry" to what is today termed the individual employment relationship (Du Toit 2008). According to van Jaarsveld and Ingrid (2008) many conditions of employment are influenced by the legislation and work agreements, with the effect that the function of the individual employment contract is regarded mainly to improve most of those conditions already provided for by other sources. South African labour legislation allows the parties in the relationship to conclude collective agreements which will later serve as terms and statutory employment protection rights (Deakin 2000).

According to Laubacher and Malone (2000:6) a valid contract of employment provides job security; health insurance; pension; career advancement prospects; a sense of belonging; and identity. In an industry where valid contracts of employment are scarce, employees are not able to access these important needs.

\subsection{Types of contracts}

Contracts of employment may be entered into either for a fixed defined period of time (fixed-term contract of employment), or they may be entered into for an indefinite period of time (indefinite-period contract of employment) (ILO 2002).

\subsection{Fixed-term contracts}

Where the parties clearly specify the duration of their contract (by date or by the completion of some task or event), there is no room for any implied term of duration and the contract will be valid for the detailed period. The only way in which a fixed-term contract of employment may be terminated before its expiry date, is by an agreement between the parties or as a result of a breach of contract by one of the parties (Grossett 2002).

\subsection{Indefinite-term contracts}

Where a contract of employment does not specify an actual date of termination or a determinable date of termination 
(such as the completion of a certain job), the contract will be for an indefinite period, with no automatic expiry date. It will endure until it is terminated in terms of the provisions of a law of statute, dismissal or in the case of a serious breach (Grossett 2002).

When an employee starts work, he/she must be given a number of prescribed particulars in writing, in the form of a written contract of employment. The written contract of employment is there to prevent memory from failing and confusion from occurring (Spoelstra \& Pienaar 2002). The Basic Conditions of Employment Act requires employers to supply their employees at the commencement of employment with the particulars of employment that must be recorded in writing. Inter alia, the following are of interest in the current study:

$>$ The employee's and employer's names and addresses.

$>$ The employee's occupation or a brief description of the work for which the employee is employed.

$>$ The employee's normal work hours and work days.

$>$ The employee's wage or the rate and method of calculating wages.

$>$ Overtime, (if any).

Any other payments in cash or in kind to which the employee is entitled (and, for payments in kind, the value of those payments).

$>$ Details of any deductions that will be made from the remuneration (Unemployment Insurance Fund, Skills Development Levy, trade union dues, etc).

$>$ The amounts of leave which can or must be taken (family responsibility leave, annual leave, sick leave, study leave, maternity leave, etc).

$>$ The period of notice (or for a fixed period contract, the date when employment terminates) (CCMA 2002:1-11).

If these particulars are in writing, many of the disagreements which may arise will be referred to the written contract and thereby, provide a clear ruling as to exactly what the requirements are. Where the employee is illiterate and does not understand the language of the employer, this document should be interpreted in a language understandable to the employee (Meintjes 1992). If any of these matters change during the contract of employment, the written particulars must be changed and the employee given a copy of the document reflecting the change (Tood 2001). Employment relations problems, in most cases, arise from the interpretation and invalidity of a contract of employment (Spoelstra \& Pienaar 2002). Implied and verbal contracts of employment create labour conflicts and disputes. Therefore, it has become customary in South Africa, for newly appointed employees to receive a letter of appointment or to conclude a full contract of employment (Bendix 2001).

\section{Problem Statement}

Domestic workers are among the most exploited groups in a society marked by extreme inequalities. This exploitation has been unchallenged, as it has been noted that some domestic workers sign invalid contracts of employment with their employers on appointment (Ngidi 2003). It is imperative that an employment contract is given careful consideration because it is more than a mere formality when employing a domestic worker. Domestic workers are more agreeable to the demands of their employers at the inception of employment. Therefore, domestic employers should utilise this opportunity to secure a favourable legal position to safeguard against possible liability (Venter 2008).

The employment relationship in the domestic services sector is more often than not an unequal relationship in which the employer (householder) holds more power than the employee (domestic worker). In these circumstances, it can be construed that an employee might enter into a contract, which could lead to his/her exploitation (Ntisa 2005). The conclusions of invalid contracts in this sector are further perpetuated by the illiteracy of job seekers who target this market for employment. Since the domestic sector is dominated by black females (refer to figure 4), it is important to note that their educational levels are marginally related to their home management and household attributes (Hendricks 1997). For instance, the Basotho people believed that educating females was a waste of resources because the ability to read and write was considered to be sufficient education for females (Ntisa 2005). This implies that domestic workers are excluded from a contract of employment that offers job security and from legal categories to which basic worker rights are formally granted. This is contrary to the Constitution of the Republic of South Africa which states that every individual has the right to freedom of trade, occupation and profession (Venter 2008).

In the context of domestic employment, there are seldom negotiations where domestic workers could present demands. In this vacuum in which there are no collective agreements or a code of conduct, more often than not, the domestic employer sketches an arrangement that the worker either accepts or rejects. Employers abuse this power; thus, the contract of employment could become a device for entering into legally unsupervised relations (Meintjes 1992). The 
power of the domestic employer to disobey the law is strengthened by the following factors.

$>$ The shift of large numbers of jobs from large- to medium- and small-sized businesses; and

> The high unemployment rate among illiterate individuals prompts employers to conclude contracts of employment that these job seekers would refuse if they knew that they could find a job with more reasonable conditions elsewhere (Meadows 2001).

\section{Empirical Study}

According to Knowles in Ngidi (2003), clues as to what people ought to learn for their own good, can be obtained from the individuals themselves. In order to achieve this plan, it is necessary to conduct a survey, based on the available literature, which forms part of the theoretical basis to describe the value of the valid contract of employment. In addition, a qualitative survey in the form of structured interviews was conducted to elicit the perceptions and ideas of domestic workers concerning their job security. According to Boyce (2002), the target population is a clearly defined group of entities that have some of the characteristics relevant to the studies in common; whereas Hair, Bush and Ortinau (2002) view the target population as an identified group of elements that are of interest to the researcher. The target population in this study comprises domestic workers in the area of Vanderbijlark in southern Gauteng. The areas covered include: South-west 1; South-west 2; South-east 3; South-west 5; and South-west 5x1.

\subsection{Population and Sample}

It is suggested that once the target population has been defined, the researcher should assemble a list of all eligible sampling units, which is referred to as the sample frame (Surujlal 2003).

In this research a non-probability sampling method was used. Bless and Higson-Smith (1995) describe this sampling method as the most rudimentary. Questionnaires were administered and interviews were conducted with the domestic workers who happened to be at the particular shopping centre or bus stop, at the particular time when the researcher was present for such purposes.

Accidental sampling was chosen, because it is the most convenient method of collection of members of the population (units of analysis) that are near and readily available for research purposes (Welman and Kruger, 2002). Maps and population statistics of all households in the area of Vanderbij|park and the vicinity, which include: South-west 1. South-west 2, South-east 3, South-west 5, and South-west 5x1, were used for selecting domestic workers who participated in the survey.

Two-hundred-and-three participants $(n=203)$ were used in this study. It was unnecessary for all subjects to have an equal chance of being selected. It should be noted that the sample size does not entitle the researcher to make assertions regarding job security amongst domestic workers in general. However, a certain phenomenon has emerged which may be applicable or be of relevance to domestic workers as a whole. The researcher will therefore, discuss the ramifications of the research findings predominantly within the parameters of the sample population $(n=203)$.

Survey research design was used in this study, which aims at the collection of qualitative data. In determining the impact of the contract of employment on the job security of domestic workers, questionnaires and structured interviews were used. To gather information, questionnaires were distributed to various the sample groups. The survey design was chosen because it would enable the researcher to obtain accurate information from all the participants.

\subsection{Measuring instruments}

The method of data collection used in order to elicit information regarding job security, consisted of questionnaires and interviews. The questionnaires were administered to domestic workers from the identified suburbs. Closed questions were utilised in the construction of interviewing schedules. Interviews were used in cases of illiteracy, as per the format of the questionnaire.

In order to investigate the accuracy or the truth of the research hypothesis of the study, it was necessary to determine the dependent, appearing variable (Welman \& Kruger, 2002). Mouton, in Ngidi (2003), states that the first general principle in data collection is that the inclusion of multiple sources of data collection in a research project, is likely to increase reliability.

Prior to commencing with the interview, the respondents were informed that the researcher was writing a book about domestic workers. The researcher thanked the interviewees for their participation and assured them of absolute 
confidentiality regarding the content of their discussions. At this point, the researcher answered any question that was posed by the respondents. When the researcher was confident that the interviewees were comfortable with the procedure and fully understood their role, the interviews proceeded.

\subsection{Data analysis}

Once data had been collected from the above-mentioned empirical analysis, the method of continuous and descriptive statistical techniques was used to provide the researcher with the summary calculations of obtained data. All the codes were captured into the statistical program for the social sciences (SPSS), in order to elicit information from the raw data, which were sent to a statistician, who analysed these.

\section{Results and Discussions}

Table 1 contains summary of the findings. The results indicate that majority of domestic employers do not comply with the relevant Acts that govern the employer-employee relationship. Results and discussions have been organised in terms of themes and issues emerging from the questionnaire.

Table 1: Contents of the contract of employment

\begin{tabular}{|c|c|c|c|c|c|c|c|c|c|c|c|c|}
\hline Question & \multicolumn{6}{|c|}{ Workers with contracts } & \multicolumn{6}{|c|}{ Workers without contracts } \\
\hline & \multicolumn{2}{|c|}{ Yes } & \multicolumn{2}{|c|}{ No } & \multicolumn{2}{|c|}{$\mathrm{N} / \mathrm{A}$} & \multicolumn{2}{|c|}{ Yes } & \multicolumn{2}{|c|}{ No } & \multicolumn{2}{|c|}{$\mathrm{N} / \mathrm{A}$} \\
\hline & Freq & $\%$ & Freq & $\%$ & Freq & $\%$ & Freq & $\%$ & Freq & $\%$ & Freq & $\%$ \\
\hline 1 & 54 & 79.4 & 13 & 19.1 & 0 & 0.0 & 47 & 43.5 & 59 & 54.6 & 2 & 1.9 \\
\hline 2 & 29 & 42.6 & 26 & 38.2 & 6 & 8.8 & 9 & 8.3 & 81 & 75.0 & 13 & 12.0 \\
\hline 3 & 47 & 69.1 & 20 & 29.4 & 1 & 1.5 & 19 & 17.6 & 87 & 80.6 & 1 & 0.9 \\
\hline 4 & 55 & 80.9 & 13 & 19.1 & 0 & 0.0 & 57 & 52.8 & 47 & 43.5 & 2 & 1.9 \\
\hline 5 & 57 & 83.8 & 11 & 16.2 & 0 & 0.0 & 54 & 50.0 & 51 & 47.2 & 3 & 2.8 \\
\hline 6 & 2 & 2.9 & 8 & 11.8 & 57 & 83.8 & 6 & 5.6 & 18 & 16.7 & 84 & 77.8 \\
\hline 7 & 2 & 2.9 & 7 & 10.3 & 58 & 85.3 & 5 & 4.6 & 24 & 22.2 & 79 & 73.1 \\
\hline 8 & 39 & 57.4 & 17 & 25.0 & 10 & 14.7 & 25 & 23.1 & 65 & 60.2 & 9 & 8.3 \\
\hline 9 & 40 & 58.8 & 20 & 29.4 & 8 & 11.8 & 32 & 29.6 & 71 & 65.7 & 5 & 4.6 \\
\hline 10 & 10 & 14.7 & 21 & 30.9 & 35 & 51.5 & 4 & 3.7 & 34 & 31.5 & 69 & 63.9 \\
\hline 11 & 48 & 70.6 & 16 & 23.5 & 3 & 4.4 & 30 & 27.8 & 70 & 64.8 & 7 & 6.5 \\
\hline 12 & 47 & 69.1 & 18 & 26.5 & 3 & 4.4 & 13 & 12.0 & 88 & 81.5 & 5 & 4.6 \\
\hline 13 & 11 & 16.2 & 46 & 67.6 & 10 & 14.7 & 6 & 5.6 & 93 & 86.1 & 8 & 7.4 \\
\hline
\end{tabular}

With regard to question 1 which states that the employer makes provision for a job description, $79.4 \%$ of domestic workers with contracts indicated that their employers made provision for a job description. This is satisfactory for an employee with a contract, since a job description should be part of the contents in the contract of employment. A total of $54.6 \%$ of domestic workers without contracts indicated that their employers made no provision for a job description. Omissions such as this result in problems that contribute to a high turnover in the domestic sector, as some domestic workers accept employment without a proper understanding of the full details of his/her duties.

With regard to question 2 which states that employer makes provision for the termination of employment, $42.6 \%$ of domestic workers with contracts indicated that their employers made provision for the termination of employment. There are some rules and regulations from the Labour Relations Act that guide both employer and employee when terminating the contract, and such rules come in the form of a contract of employment. A total of $75.0 \%$ of domestic workers without contracts indicated that their employers do not make provision for a procedure for the termination of employment. This is not in compliance with the LRA, which provides for certain procedures for the declaration of unfair dismissals, as opposed to the position of other unfair labour practices.

With regard to question 3 which states that the employer makes provision for wage increment, $69.1 \%$ of domestic workers with contracts indicated that their employers made provision for wage increments and that this was part of the contents of their contracts. A total of $80.6 \%$ of domestic workers who do not have legal contracts with their employers indicated that their employers do not make provision for wage increments. This is not in compliance with the sectoral rule, which stipulates that every domestic worker be granted an annual wage increase of at least $8 \%$ on 1 November 
2003 and 2004. Some of these employees indicated, during interviews schedules, that they had been in employment with the same employer for more than ten years but were still earning at a level that does not enable a certain minimum standard of living to be maintained.

With regard to question 4 which states that the employer makes provision for the hours of work, $80.9 \%$ of domestic workers with contracts indicated that their employers made provision for the hours of work. A total of $52.8 \%$ of domestic workers without contracts indicated that their employers do make provision for the hours of work, while $43.5 \%$ of domestic workers without contracts indicated that employers do not make provision for the hours of work. It is assumed that these workers are those who reside at the workplace, where the employer misuses his/her powers by making workers work beyond the overtime limit of three hours per day. This is particularly relevant, because if domestic workers do have legal contracts of employment and the issue of working hours forms part of the contract, such workers would be in a position to question/challenge excessive working hours as per rule of the employer who does not abide by the law. However, Friguglietti (1989) concedes that the allocation of fixed hours for household work is often impractical, given the nature of the work and the varying demands made by employers.

With regard to question 5 which states that employer makes provision for meal intervals, $83.8 \%$ of domestic workers with contracts indicated that their employers do make provision for meal intervals. A total of $47.2 \%$ of domestic workers indicated that their employers do not make provision for meal intervals. These employees, during the interview schedules, indicated that they work from seven o'clock in the morning until six o'clock in the evening, but that their lunchtime duration is a maximum of thirty minutes, without teatime in the morning or in the afternoon.

With regard to question 6 which states that the employer makes provision for payment for Sunday work, $83.8 \%$ of domestic workers with contracts and $77.8 \%$ of domestic workers without contracts, indicated that the question did not apply to their situation of employment. This is because they do not work on Sundays. This correlates with regard to question 7 which states that the employer makes provision for payment for public holidays; $85.3 \%$ of domestic workers with contracts and $73.1 \%$ of domestic workers without contracts indicated that the question was not applicable, since they did not work on public holidays.

With regard to question 8 which states that the employer makes provision for annual leave, $57.4 \%$ of domestic workers with contracts indicated that their employers do make provision for annual leave. A total of $60.2 \%$ of the domestic workers indicated that their employers do not make such a provision. These employees reported, during the interview schedules, that even if employers provided such leave, they did not get paid (unpaid annual leave). This is contrary to the Basic Conditions of Employment Amendment Act which states that domestic workers must be granted at least 14 consecutive days' leave on full pay for each completed year of service with the same employer (Huber \& Sack 1994).

With regard to question 9 which states that the employer makes provision for sick leave, $58.8 \%$ of domestic workers with contracts indicated that their employers made provision for paid sick leave. A total of $65.7 \%$ of domestic workers without contracts indicated that their employers do not make any provision for sick leave. These employees indicated, during the interview schedules that if they become sick, they are not remunerated for the days they took off (unpaid sick leave).

With regard to question 10 which states that employer makes provision for maternity leave, $30.9 \%$ of domestic workers with contracts indicated that their employers did not make provision for maternity leave; while $51.5 \%$ of the domestic workers with contracts indicated that this question was not applicable. A total of $63.9 \%$ of the domestic workers without contracts indicated that this question was not applicable. This was because some of these employees were beyond the age of fertility, while some were males to whom maternity leave did not apply.

With regard to question 11 which states that the employer makes provision for family responsibility leave, $70.6 \%$ of the domestic workers with contracts indicated that their employers made provision for paid family responsibility leave. A total of $64.8 \%$ of the domestic workers without contracts said that their employers did not make provision for family responsibility leave.

With regard to question 12 which states that the employer provides for a deduction from remuneration, $69.1 \%$ of the domestic workers with contracts showed that their employers made deductions from their salaries. Most of these deductions were made for the Unemployment Insurance Fund (UIF). A total of $81.5 \%$ of the domestic workers without contracts indicated that their employers did not make any deductions from their salaries. They declared that they were not registered with the UIF or for any other relevant benefits.

With regard to question 13 which states that the employer makes provision for training to improve job skills, $67.6 \%$ of the domestic workers with contracts declared that their employers did not make any provision for training in order to improve their skills. A total of $86.1 \%$ of the domestic workers without contracts indicated that their employers equally, did 
not make any provision for training. This then demonstrates that employers in the domestic sector do not consider the skills improvement of their employees as important in carrying out their duties thoroughly. This is supported by Vavi (2005) that for most black workers, there has been no improvement in access to training and job security.

\section{Conclusion}

It can be concluded that a contract of employment should play an important role in clarifying what is to be expected from each party. The greater the clarity as to what is expected from each contractual party, the less the chance there is of misunderstandings in the relationship. Thus, no matter how widely domestic workers are covered by labour laws in the new South Africa, and no matter the efficiency of South African labour legislation, domestic workers will continue to be disadvantaged and exploited by their employers if they continue to form employment relationships in the absence of valid contracts of employment. The researcher further submits that the success of legislation in the domestic sector will depend largely on the resolve of both parties (employer and his/her domestic worker), to ensure that they both ultimately benefit by adapting the provisions of the legislation to their respective joint interests, through a valid contract of employment.

Having signed valid contracts of employment and with domestic workers possessing copies of such contracts, it will allow domestic workers to be placed on a firm legal footing with their employers. This will once and for all settle the problems of identity, profile and recognition, which domestic workers may experience with their employers.

\section{References}

Anon. 2006. All bunged up. Economist, 380(8496):1-2.

Bendix, S. 2001. Industrial relations in South Africa. $4^{\text {the }}$. Cape Town: Juta and Co, Ltd.

Bless, C \& Higson-Smith, C. 1995. Fundamentals of social research methods: an African perspective. $2^{\text {nded. }}$. Cape Town: Juta.

Boyce, J. 2002. Marketing research in practice. Sydney: McGraw-Hill.

Clark, J.R. 2007. Positional assessment and physical fitness characteristics of male professional soccer players in South Africa. African journal for physical, health education, recreation and dance, 13(4):453-464, Dec.

Commission For Conciliation, Mediation \& Arbitration. 2002. Employment contracts. [online]. Available at: <http://www.ccma.org.za /displaypage.asp?id=36\&MainCat=Employment+Contracts>. Accessed: 5/18/2004.

Deakin, S. 2000. The main futures of the contract of employment. Economic and Social Research Council: University of Cambridge.

Du Toit, D. 2008. Oil on troubled waters? The slippery interface between the contract of employment and statutory labour law. South African Law Journal, 125(1):95-133.

Dubihlela, J., Dhurup, M., Surujlal, J. 2009. Motivational factors affecting fan decisions to attend premier soccer league PSL games in South Africa. African journal for physical, health education, recreation and dance, 15(4):155-171.

Friguglietti, R. 1989. Domestic workers: Dependency vs. self-assertiveness in the workplace. MA. Thesis. Pretoria: UP.

Grogan, J. 2011. Dismissal. Cape Town: Juta.

Grossett, M. 1994. Your domestic worker and the law. Cape Town: Southern African Publishers.

Grossett, M. 2002. Discipline and dismissal. 2nded. Cape Town: Oxford.

Hahlo, H \& Kahn, E. 1968. The South African legal system: and its background. 6thed. Cape Town: Juta \& Co.

Hair, S., Bush, P \& Ortinau, D. 2002. Marketing research within a changing information environment. $2^{\text {nd }}$ ed. Boston: McGraw.

Hendricks, S. 1997. Successful skills training in relation to home management and household attributes. Tydskrif vir dieetkunde en huishoudkunde. 25(2):153-154.

Huber, M \& Sack, P. 1994. Employing a domestic worker. 2nd. Cape Town: Metz Press.

International Labour Organization. 2002. Contracts of employment: Social dialogue. [online]. Available at: <http://www.ilo.org/public lenlish/dialoque/themes/ce.htm>. Accessed: 9/29/2004.

Laubacher, R., \& McGovern, T. 2000. Retreat of the firm and the rise of guilds: the employment relationship in an age of virtual business.

Meadows, P. 2001. Beyond employment: changes in work and the future of labour law in Europe. Kalahari: Oxford University Press.

Meintjies, L. 1992. The domestic worker: Some considerations for the law reform. LL.M. Dissertation. Port Elizabeth: RU.

Nel, P.S., Kirsten, M., Swanepoel, B.J., Erasmus, B.J., \& Poisat, P. 2008. South African employment relations: theory and practice. $6^{\text {th }}$ ed. Pretoria: Van Schaik.

Nematswerani, H.E., \& Mars, M. 2005. A comparison of the nature and severity of injuries in younger and older professional soccer players. South African Journal of Sports Medicine, 17(3):12-18.

Ngidi, B. 2003. An assessment of the home management training needs of domestic workers in selected regions of the Ethekwini Municipal Area. M Phil. Thesis. Eastern Cape: University of Stellenbosch.

Ntisa, A.A. 2005. Contract of employment and its impact on the job security of domestic workers. MTech. Dissertation. Vanderbijpark: VUT. 
Ontario. 2013. Employment standards: domestic workers. [online]. Available at: <http://www.gov.on.ca/LAB/English/es/factshets /fs_domestics.html>. Accessed: 9/29/2013.

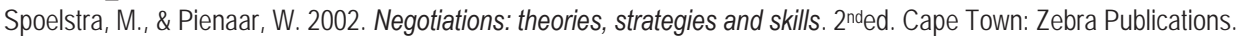

Surujlal, J. 2003. Human resources management of professional sport coaches in South Africa. D.Phil.Thesis. Johannesburg: RAU.

Tood, C. 2001. Contracts of employment. Cape Town: Siber Ink CC.

Van Jaarsveld, M \& Ingrid, M. 2008. The role of contractual principles in contemporary employment relationships in Germany: is there a lesson to learn for South Africa? Part 1. Obiter, 29(1): 19-32.

Van Jaarsveld, M. 2003. The validity of restraint of trade clause in an employment contract. South African Mercantile Law Journal, 15:237-326, Mar.

Van Jaarsveld, M. 2008. Contract of employment: weathering storms in mixed jurisdictions? Some comparative thoughts. Electronic Journal of Comparative Law, 12(1) 1-26.

Vavi, Z. 2005. Workers' voice: Cosatu's jobs campaign continues with mass marches. City Press, p.2, 09 Oct.

Venter, A.J. 2008. Employment contracts pitfalls: legal update. Enterprise Risk, 2(1): 24-25, Jan.

Venter, R., \& Levy, A. 2011. Labour relations in South Africa. $4^{\text {th }}$ ed. Cape Town: Oxford.

Welman, J \& Kruger, S. 2002. Research methodology. $2^{\text {nd }}$ ed. Cape Town: Oxford University Press. 